\title{
51. RECONNAISSANCE D'ETOILES APPARTENANT AU GRAND NUAGE DE MAGELLAN A L'AIDE D'UN PRISME OBJECTIF A CHAMP NORMAL
}

\author{
M. et A. Duflot et C. Fehrenbach* \\ Observatoire de Marseille
}

La méthode de mesure des vitesses radiales au prisme objectif à champ normal que nous employons à l'Observatoire de Haute Provence depuis de nombreuses années (Fehrenbach 1947, 1948, 1955) est la méthode idéale pour la recherche des étoiles de grande luminosité, membres des Grand et Petit Nuages de Magellan.

Dans ce but nous avons construit un instrument identique au grand prisme objectif de l'Observatoire de Haute Provence que nous avons décrit par ailleurs (Couder et Fehrenbach 1958). Cet instrument a été installé en Afrique du Sud à Zeekoegat $\left(L=1^{\mathrm{h}} 29^{\mathrm{m}} 5 \mathrm{E}, l=-35^{\circ} 5^{\prime}\right)$ dans la Province du Cap. Cet instrument initialement construit pour une Station française est maintenant transféré à l'Observatoire Européen Austral (E.S.O.). Pour diminuer les délais d'installation, c'est l'optique et les tubes de lunettes de l'Observatoire de Haute Provence qui ont été montés en Afrique du Sud. Cet instrument sera désigné par le sigle GPO2. Nous en donnons les caractéristiques:

Objectif: diamètre $38,5 \mathrm{~cm}$; distance focale $399,4 \mathrm{~cm}$;

prisme: diamètre $40 \mathrm{~cm}$;

dispersion: $110 \AA / \mathrm{mm}$ vers $\lambda=4210 \AA$;

champ: $2^{\circ} \times 2^{\circ}$.

La grande distance focale a été choisie spécialement, il est facile de montrer (Fehrenbach 1963) que la magnitude limite pour une dispersion donnée ne dépend que de la distance focale du prisme objectif. Avec notre dispersion de $110 \AA / \mathrm{mm}$ entre $\mathrm{H}_{\gamma}$ et $\mathrm{H} \delta$ cette magnitude limite est de 12,5. La pose nécessaire est de $2 \times 2^{\mathrm{h}}$ avec des plaques Kodak IIaO chauffées, chaque spectre ayant une hauteur $h=0,250 \mathrm{~mm}$. Pour une pose plus longue, le cliché est voilé par la lumière du fond du ciel et les superpositions de spectres sont trop nombreuses surtout dans les Nuages de Magellan. Nous atteignons toutes les étoiles des catalogues HD et HDE avec une pose de $2^{\mathrm{h}}$. Nous dépassons d'ailleurs nettement les limites de ces catalogues (Fig. 1).

L'instrument a été installé à Zeekoegat dans un abri spécialement construit pour lui. Nous avons étudié cet abri pour protéger l'instrument des trop fortes variations de température (double toit et conditionnement d'air). Le montage et les réglages ont été faits par les techniciens et les astronomes de l'Observatoire de Marseille. Par suite des difficultés normales dans des conditions d'isolement (à $50 \mathrm{~km}$ de la petite ville la plus proche), l'installation n'a été prête pour le travail astronomique qu'en janvier 1962 au moment où le Grand Nuage de Magellan n'était observable que pendant peu de temps au voisinage du méridien.

Les conditions de travail sur les Nuages de Magellan sont assez difficiles.

* Présenté par G. Courtès. 
$1^{\mathrm{e}}$ - La situation de ces Nuages assez près du pôle Sud nécessite une orientation parfaite de l'instrument, d'autant plus nécessaire que les poses sont longues.

$2^{e}$ - Un prisme objectif de la dimension du GPO2 est évidemment très sensible aux fortes variations de température et malgré les soins que nous avons apportés à l'isolement thermique, l'expérience montre qu'il faut ajuster souvent la mise au point. Par fortes variations de température, les spectres ne sont pas de première qualité.

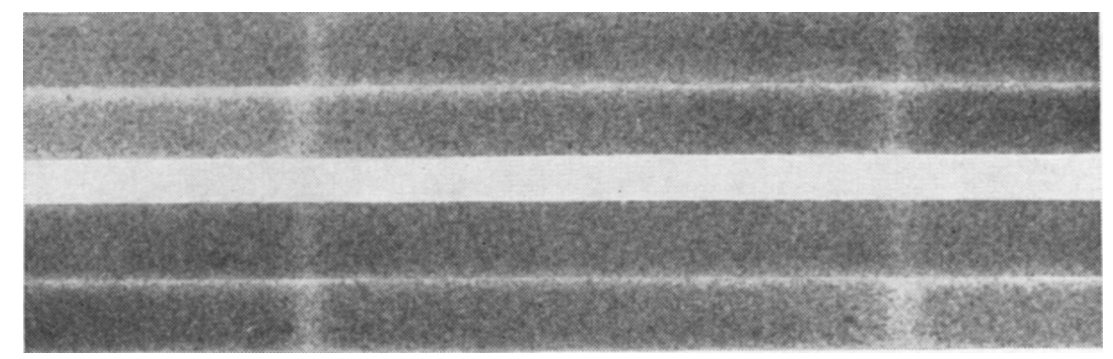

Fig. 1.-Une étoile à grande vitesse radiale du Grande Nuage de Magellan. (a) Le Grand Nuage de Magellan, HD 270033; (b) la Galaxie, HD 270034.

\section{Clichés}

En 1961-1962, nous avons obtenu un certain nombre de clichés sur le Grand Nuage de Magellan, essentiellement dans quatre régions de $2^{\circ} \times 2^{\circ}$, centrées sur les étoiles:

$\begin{array}{crrr}\text { CPD } & \alpha & 1875 & \delta \\ -68^{\circ} 377 & 5^{\mathrm{h}} 28^{\mathrm{m}}, 2 & -68^{\circ} & 10^{\prime} \\ -69^{\circ} 336 & 10^{\mathrm{m}} 4 & -69^{\circ} 52^{\prime} \\ -66^{\circ} 421 & 29^{\mathrm{m}}, 4 & -66^{\circ} 32^{\prime} \\ -67^{\circ} 515 & 47^{\mathrm{m}}, 8 & -67^{\circ} 48^{\prime}\end{array}$

Nous avons déjà publié des résultats préliminaires pour le premier champ (Fehrenbach et Duflot 1962). Ces résultats seront complétés. Dans l'étude actuelle nous donnons des résultats sur les trois autres champs. Ces clichés ont été examinés une première fois par l'un de nous en projetant l'image des spectres agrandis 12,5 fois sur un écran diffusant. Ceci permet de reconnaître très facilement toutes les étoiles à grande vitesse radiale appartenant au Nuage, et d'obtenir des coordonnées approximatives de ces étoiles. Dans cette liste nous avons inclus les étoiles douteuses (sous exposées, surexposées, et superposées).

Les clichés ont été ensuite examinés avec un spectrocomparateur (Duflot et al. 1958) ce qui nous a permis de confirmer la plupart des étoiles de la liste provisoire, d'en éliminer quelques unes qui restaient très douteuses. Pour quelques étoiles un doute subsiste: celles dont les spectres sont sous exposés ou superposés (nous les avons signalées comme étoiles à grande vitesse radiale probable), et quelques étoiles dont les vitesses radiales ont des valeurs intermédiaires entre celles du Nuage et de la 
Galaxie. En principe, nous avons éliminé ces étoiles que nous nous proposons de signaler ultérieurement. Cependant comme nos vitesses radiales n'ont pas été mesurées avec précision, il peut subsister dans nos listes l'une ou l'autre de ces étoiles à vitesse radiale intermédiaire. Ainsi A. D. Thackeray à qui nous avions adressé une liste provisoire nous a signalé que l'étoile HD 268957 a une vitesse radiale de $+150 \mathrm{~km} / \mathrm{sec}$. Dans ces conditions nous l'avons extraite de notre liste et l'ajoutons à la fin.

En même temps nous avons mesuré les coordonnées rectilignes de toutes les étoiles du champ à $0,1 \mathrm{~mm}$. Un ordinateur électronique français CAB 500 permet de calculer très facilement les coordonnées $X$ et $Y$ du système de Harvard (Leavitt 1908)

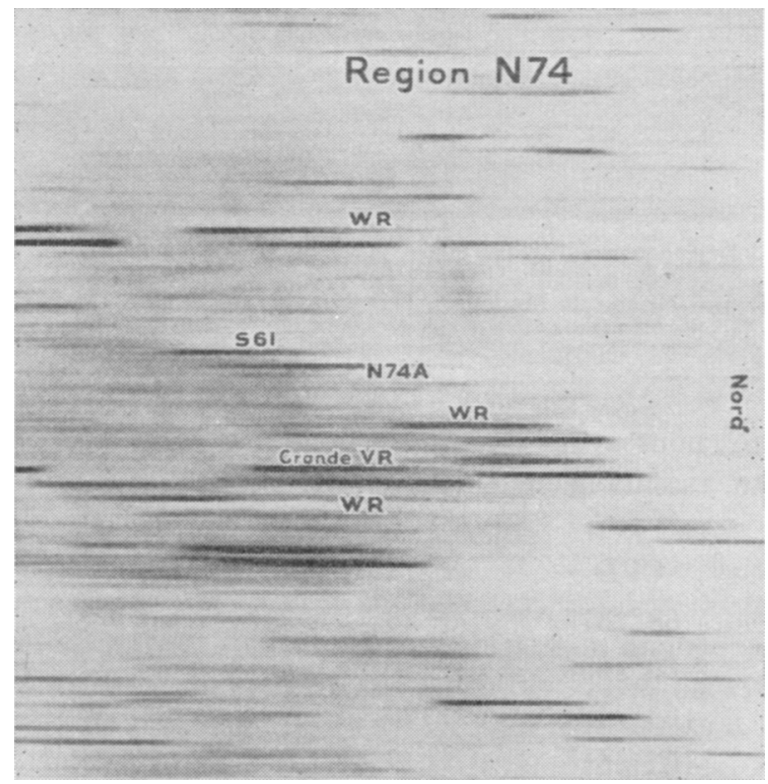

Fig. 2.-Région de la nébuleuse N74 du catalogue de Henize et ses collaborateurs. On constate le groupement dans cette région qui fait environ $15^{\prime}$ sur $5^{\prime}$, de trois étoiles de Wolf-Rayet, de la nébulosité signalée par Henize N74A qui est une nébuleuse planétaire, d'une étoile du type GK à grande vitesse radiale et qui fait donc partie du Nuage (étoile à très haute luminosité). L'étoile à émission (H en émission) $\mathrm{S61}$ du catalogue de Henize à grande vitesse radiale d'après nos mesures, est proche de l'ensemble. Elle n'est pas notée par Henize comme associée à N74.

ainsi que les coordonnées $\alpha$ et $\delta$. L'emploi de l'ordinateur est indispensable si l'on considère qu'il y a 400 à 500 étoiles par cliché. Ces coordonnées permettent une identification facile de nos étoiles. La précision de nos coordonnées est suffisante pour une identification certaine. Il semble que par la suite il serait indiqué de faire des mesures de coordonnées à $0,01 \mathrm{~mm}$ près. Ceci est surtout essentiel pour les étoiles faibles qui ne sont pas dans les catalogues et pour lesquelles les coordonnées sont con. nues avec une précision de $\Delta \alpha= \pm 0 ; 02, \Delta \delta= \pm 0,2$. Nous ne publions ici que les 
listes d'étoiles à grande vitesse radiale. Nous publierons ultérieurement les listes des étoiles de petite vitesse radiale reconnues dans nos champs. Nous pouvons déjà les communiquer à la demande.

La mesure très précise des vitesses radiales sur ces premiers clichés de prisme objectif s'est avérée assez difficile surtout pour les étoiles faibles. Ceci ne doit pas nous surprendre, d'une part, nos premiers clichés ne sont pas excellents ayant été pris pendant la période de réglages, d'autre part, pour les étoiles faibles, le contraste des raies est fortement diminué par la brillance du fond du ciel. Pour les étoiles supergéantes $(0, B$, et $A)$, le contraste des raies est déjà normalement très faible ce qui augmente les difficultés de mesure. Nos spectres sont déjà assez bons pour corriger certaines classifications Con. données par le catalogue Harvard (ce qui est d'ailleurs indispensable pour pouvoir faire des mesures de vitesses radiales). Néanmoins la mesure des vitesses radiales sera reprise dès que les clichés de cette nouvelle saison seront en notre possession.

Nous signalons que la moyenne des vitesses radiales des étoiles du Nuage donne une valeur voisine de $+250 \mathrm{~km} / \mathrm{sec}$ par rapport aux étoiles de la Galaxie.

Pour les classifications spectrales, nous avons d'une part indiqué les classes du catalogue de HD, d'autre part, nous indiquons des valeurs approximatives du type spectral tel qu'il ressort d'une simple inspection de nos clichés. Cette indication ne doit pas être considérée comme définitive. Nous préciserons les types spectraux et les magnitudes dans un prochain article et nous discuterons les résultats.

Nous publions (Tables 1-3) une liste de 102 étoiles à grande vitesse radiale. Pour 84 de ces étoiles, la grande vitesse radiale est certaine, pour 17 elle est à confirmer. Nous signalons une étoile dont la vitesse radiale est intermédiaire entre déjà connues comme appartenant au Grand Nuage de Magellan. Voyez aussi la Figure 2 et la Planche 1.

\section{Explication des Colonnes}

Colonne 1.-Numéro de l'étoile dans les catalogues HD ou HDE.

Colonne 2.-Identification de l'étoile provenant de diverses sources. En particulier la dénomination $R$ correspond au catalogue publié par l'Observatoire Radcliffe (Feast, Thackeray, et Wesselink 1960).

Colonnes 3 et 4.-Coordonnées $X, Y$ du système de Harvard. Ces valeurs sont les valeurs calculées par nous à partir des coordonnées rectilignes sur nos clichés.

Colonnes 5 et 6.-Coordonnées 1875 calculées par nous.

Colonne 7.-Magnitudes et classes spectrales de Harvard.

Colonne 8.-Remarques: Nous donnons une valeur très approchée de la magnitude obtenue par une simple observation visuelle de l'intensité des spectres sur nos clichés. Le type spectral indiqué est également une première estimation rapide. Nous indiquons aussi la classe spectrale provenant d'autres auteurs. 

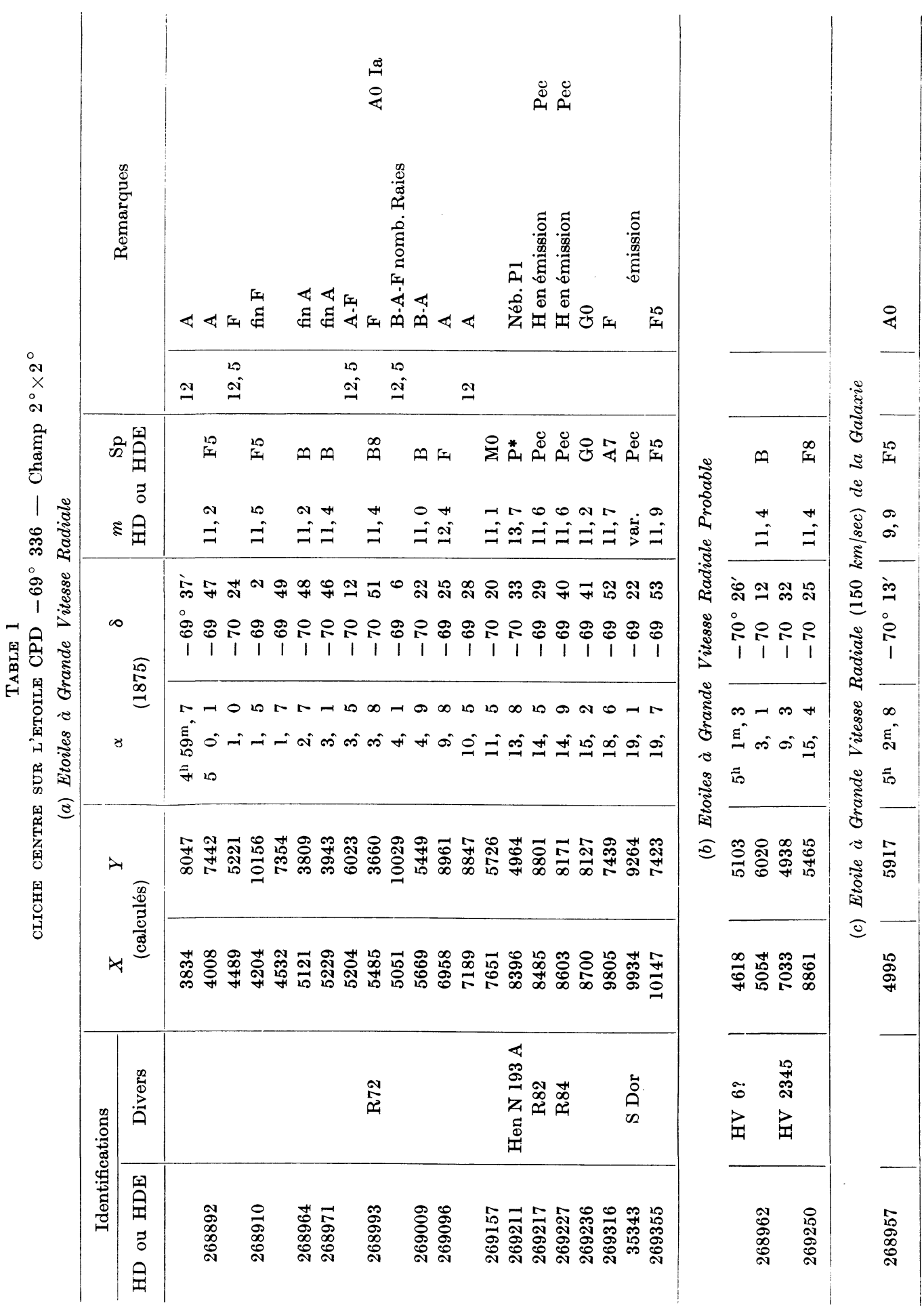
RECONyAissance D'etoIles A L'AIDE D'UN PRISME OBJECTIF

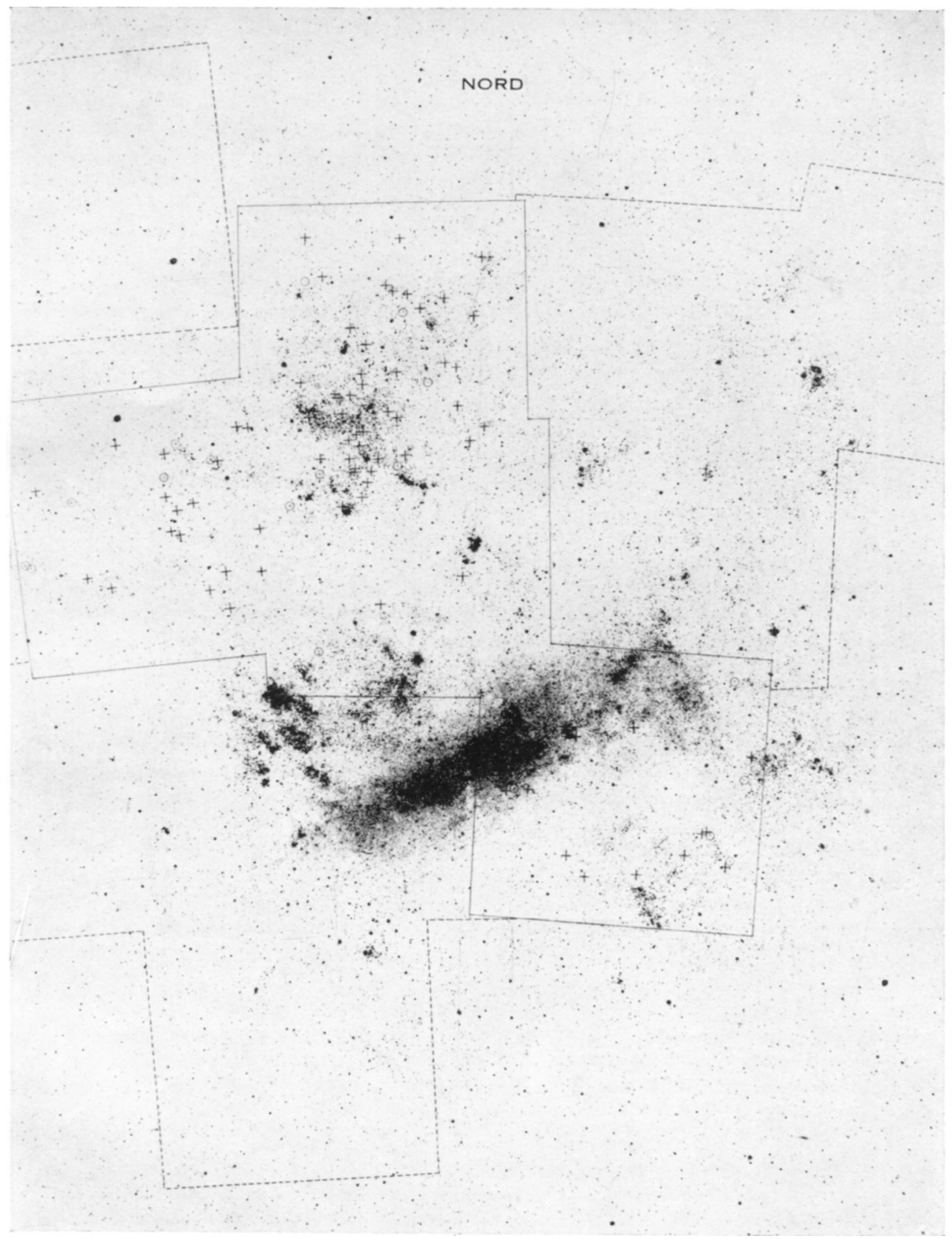

Répartition des étoiles à grande vitesse radiale. + Etoiles ()-B-A; $\bigcirc$ étoiles F-G-K. La région entourée d'un trait plein est étudiée. La région entourée d'un pointillé est au programme. On remarque le groupement des étoiles à grande vitesse radiale sur une région en bordure du grand Nuage et au rontraire des "absenees" de grandes vitesses radiales. 


\section{Bibliographie}

Couder, A., et Fehrenbach, C. (1958).-C.R. 247: 2067-70=Publ. O.H.P. $4:$ No. 32.

Duflot, M. Fehrenbach, C., Gurllaume, J., et Ray, G. (1958).-Journ. des Obs. 41: 41-2= Publ. O.H.P. 4 (1957): No. 11.

Feast, M. W., Thackeray, A. D., et Wesselink, A. J. (1960). -M.N. 121 : 337-85.

Fehrenbach, C. (1947).-Ann. d'Astr. $10: 257-81$ et 306-28.

Fehrenbach, C. (1948).-Ann. d'Astr. $11: 35-57=$ Publ. O.H.P. Série A (1951): No. 14.

Fehrenbach, C. (1955).-Journ. des Obs. 38: 165-71 = Publ. O.H.P. 3 (1954): No. 24.

Fehrenbach, C., et Duflot, M. (1962).—C.R. 254: 980-2 = Comm. E.S.O. No. 1.

Fehrenbach, C. (1963).--(sous presse.)

LeavitT H. S. (1908).-Ann. Harvard Coll. Obs. 60: 87-108.

ThaCkERAY, A. D. (1962).-M.N.A.S.S.A. 21 : 47-9.

\section{Discussion} LMC.

Perek: It is rather surprising to find a large number of early-type high-velocity stars in the

Courtès: I think that this selection between B-A stars (crosses on the graph) and F.G.K. (points) is without doubt in spite of some underexposed spectra. Perhaps a slight difference will be found in selecting $\mathbf{A}$ and $\mathbf{F}$ stars if this observation were made with a higher dispersion and stronger emulsion density. I don't think that the general aspect of this statistic would be changed.

Thackeray: I am sure that we shall all want to congratulate Dr. Fehrenbach very warmly indeed on the successful outcome of this project, which, as you may remember, was first planned at the Stockholm Symposium of 1957. The finding lists will be invaluable to those working with large reflectors in that we shall avoid wasting time on foreground stars.

In our Radcliffe slit spectroscopy, we have found that radial velocity by itself is not always a sufficient criterion for Cloud membership. Since the velocities of the Clouds reflect mainly the component of galactic rotation, one must expect some galactic foreground stars of Population II to show about the same velocity as the Clouds. We have found a few such stars at Pretoria which are rejected as Cloud members through our luminosity classifications. Can Dr. Fehrenbach's simple spectra taken for luminosity classification always be used as such a discriminant?

Courtès: I agree with you that some more detailed spectra are needed for some of these stars and one of them has been eliminated from our list under your advice, but I think that the fields taken in the vicinity of the Clouds will give less high-velocity stars, and if Professor Fehrenbach and his collaborators find this systematic decreasing of the high-velocity stars when they observe outside of the Cloud, it will be a good proof that these stars are really members of the Clouds.

Bok: Firstly - as someone who tried measuring objective-prism radial velocities in the 1930's - let me congratulate Professor Fehrenbach and Mme. Duflot on their beautiful results.

Secondly - has the prism system been turned over $90^{\circ}$ to permit measurement of stars that are now eliminated by overlapping of spectra from neighbouring stars? Thirdly - have you attempted to shorten your spectra by the use of special filters, and eliminate to some extent the effects of bright nebulosity, which tend to fill in your stellar absorption lines, especially those that are faint and narrow? Can you hope to measure stars in dense groupings such as Shapley's Constellation I?

Courtes: Of course, it is the only way to diminish the overlapping of the spectra, but it needs a special scanning in declination instead of the scanning actually used in right ascension. It is a small mechanical difficulty that we will resolve as soon as this first survey is finished.

The second way of getting more non-overlapped spectra is to use a filter to cut off the useless part of the spectra. One of the Schott filters is very convenient for that and it is also a question of mechanical difficulty which has delayed this improvement.

The dense grouping such as Shapley Constellation I will always be difficult with any objective prism. 


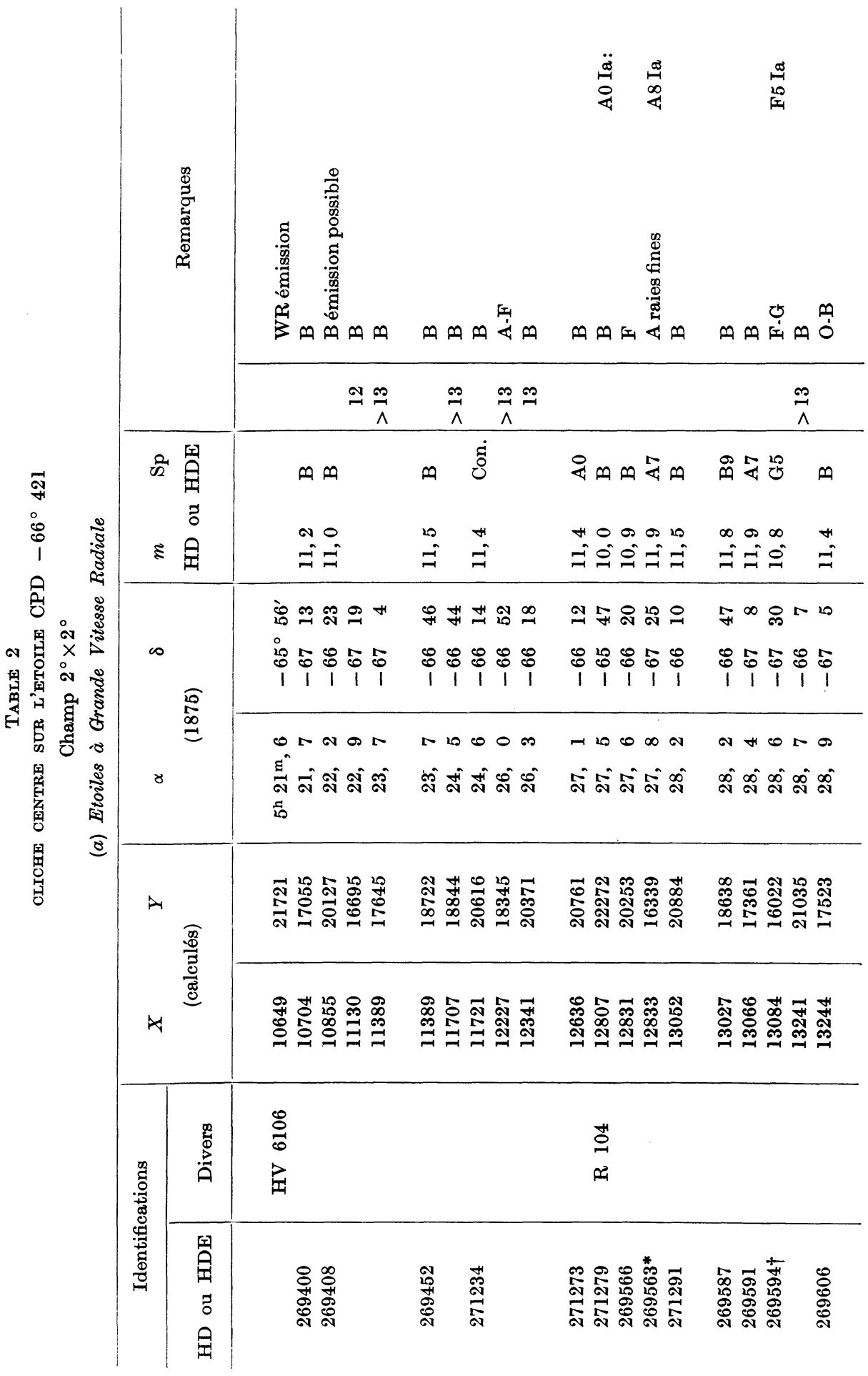




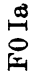

0
1
0
0
0
4

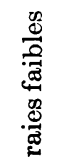

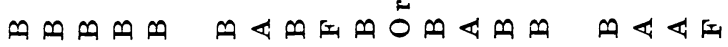

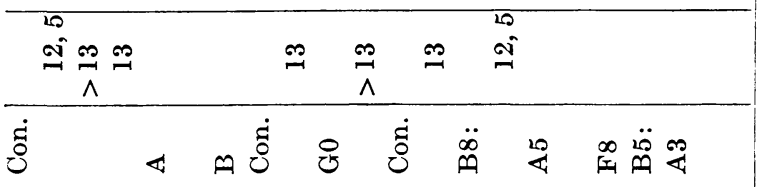

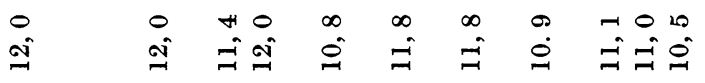

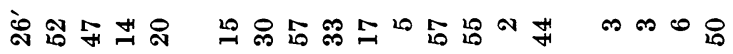

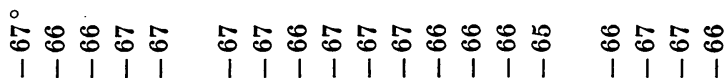

os os os o h H h H H H

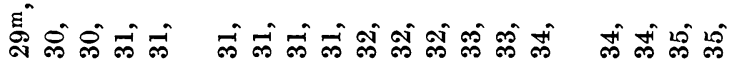
ปี

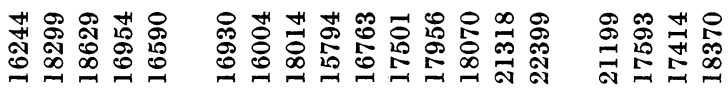

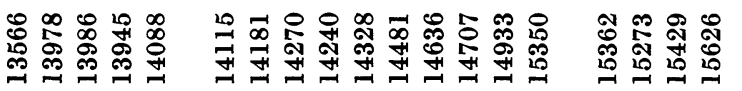

욤

番

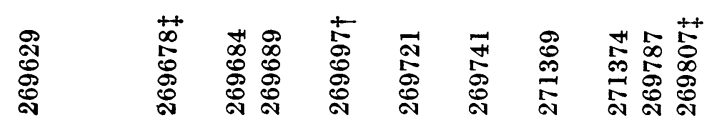

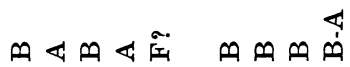
$\stackrel{\Lambda}{n} \underset{\Lambda}{n} \stackrel{\sim}{n} \stackrel{\Lambda}{n}$

$\frac{1}{3}$ 胥

: సั 눙 $\begin{array}{lllllll}1 & 1 & 1 & 1 & 1 & 1 & 1\end{array}$

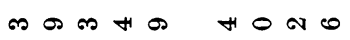

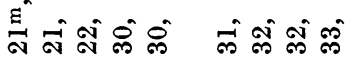
เू

这 o

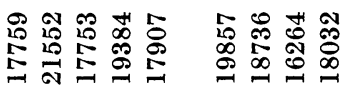

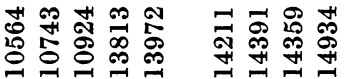




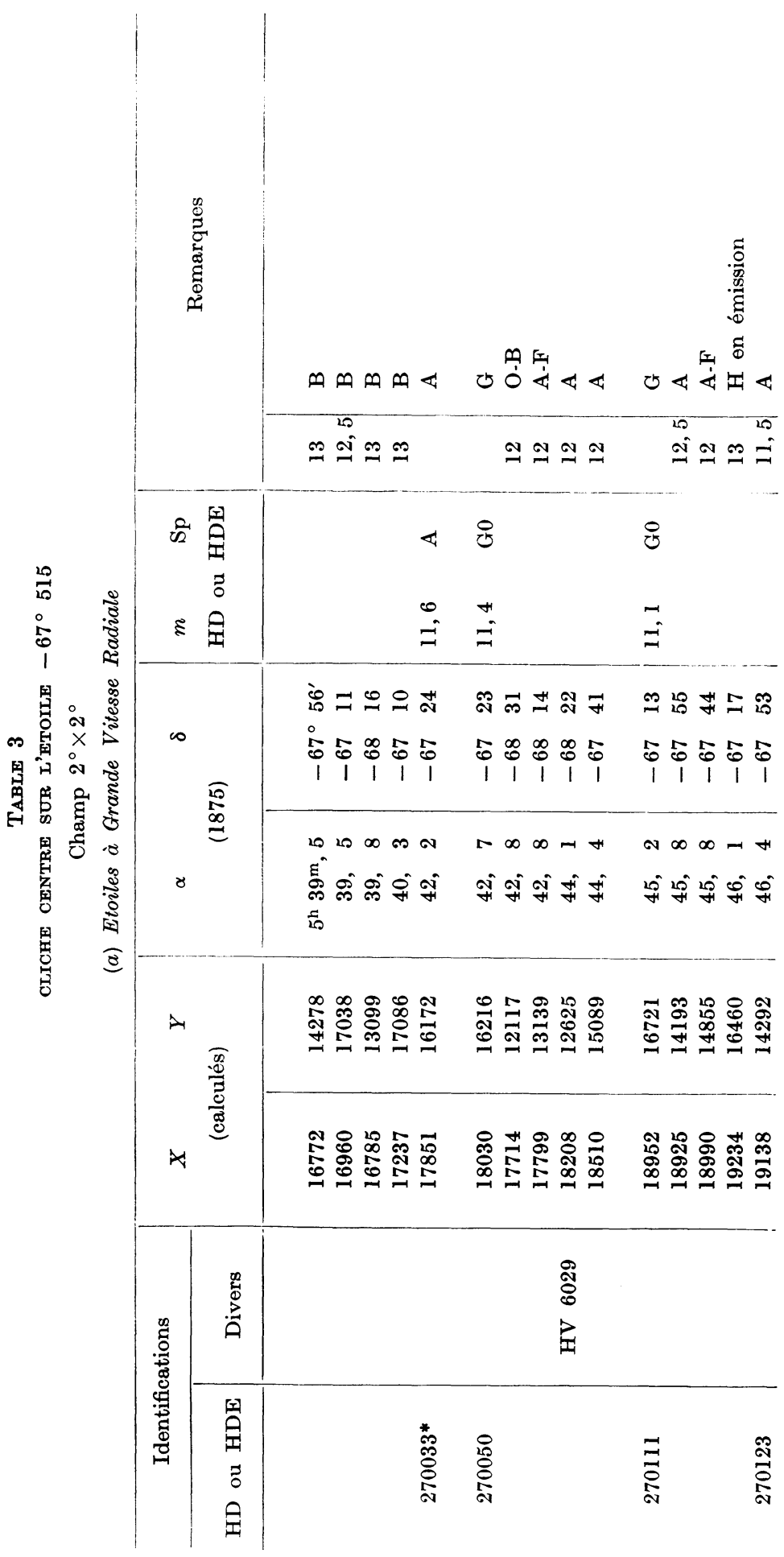




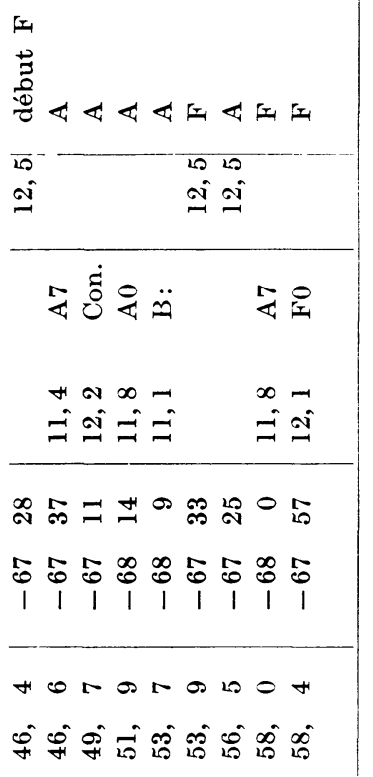

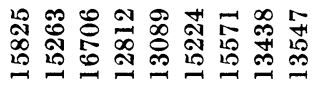

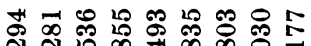

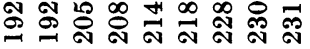

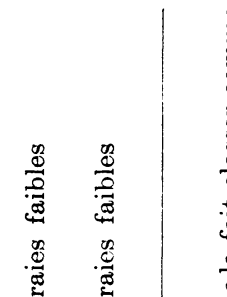

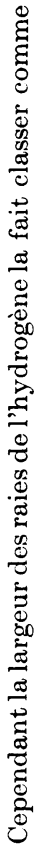

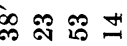

$\stackrel{\oplus}{\infty}: \infty$

1111

$0-\infty 0$

हुं

เิ

胥

อ

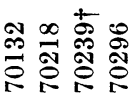

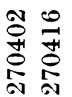


Aller: Is it possible to use a focal plane spectrograph at a large telescope with a greater focal ratio to alleviate effects of overlap of spectra of stars?

Courtès: The question of Professor Aller permits me to develop my remark about the limit in using any objective-prism techniques.

An objective prism has a focal length always limited by the seeing condition, as 1 " of seeing corresponds to $25 \mu$ for $5 \mathrm{~m}$ focal length, so you see that it is difficult to use focal length longer than $5 \mathrm{~m}$ and $I$ see the certain limit around $10 \mathrm{~m}$. When you want to use a large telescope, for example $2 \mathrm{~m}$ aperture, the focal ratio is of course too high, $2 \cdot 5$ or, at the limit, 5 , or $10 \mathrm{~m}$ equivalent focal length. That gives you a new limit in reaching faint stars because of the sky fog rising fast in relation to the focal ratio. In spite of that, $I$ have designed an adaptation of the Fehrenbach prism to the Reducteur focal usually used for nebular work - but this instrument will be equipped with filters selecting some of the most characteristic parts of the spectra. Focal ratio 3 will be used; this corresponds to approximately $6 \mathrm{~m}$ focal length.

Kerr: Professor Fehrenbach has published two examples of the frequency distribution of velocities in particular areas. These are directly comparable with 21 -cm line profiles. Is he planning to extend this form of presentation?

Courtès: Certainly, but that will be made at the end of this general survey.

Eggen: We have heard of possible connections between the two Clouds and between Clouds and the Galaxy. Is a search for these connections proposed?

Courtès: Some stars have an intermediate radial velocity and could be interpreted as intermediate distance stars - but this selection will be easier for Clouds-to-Galaxy than for Cloud-to-Cloud.

\title{
52. MEMBER STARS OF THE MAGELLANIC CLOUDS FROM PROPER MOTIONS
}

\author{
SIR RichaRd WoOLLEY \\ Royal Greenwich Observatory
}

The material which I wish to present today is set out in Royal Observatory Bulletin Number 66, of which I have a few advance copies with me. The paper describes measures of about 700 stars in an area about $1^{\circ}$ square. These are nearly all the stars down to a limit of $V=14 \mathrm{~m} 5$ in the area. Proper motions were measured by comparison between two plates taken on 1912 Jan. 21 and 1960 Nov. 16-17. The earlier plate had an exposure of $5 \mathrm{hr}$, which is exceptionally long for astrographic plates of those times. The measures of $\Delta x$ and $\Delta y$ (the shifts in units of onetenth of a micron in the directions of right ascension and declination) were reduced by constructing plate constants such as would make the least-squares motion of the stars with $B-V<0$ zero. In the reduction 104 such stars were used. The standard errors of measurement are $\sigma(x)= \pm 15 \cdot 9$ and $\sigma(y)= \pm 14 \cdot 9$, assuming that these stars really are members of the LMC and exhibit no relative proper motion. By using these plate constants, values of $\Delta x$ and $\Delta y$ were computed for all the remaining stars. The stars with $0.5<B-V<1.5$ (apart from cepheids and a few reddened stars) are very plainly shown by their proper motions to be nearly all field stars, and indeed their motions can be satisfactorily explained by supposing them to be galactic stars showing the parallactic motion, galactic rotation, and a velocity ellipse appropriate to galactic stars. Stars with $B-V>1.5$ cannot be determined to be members of the LMC on proper motion alone, but other considerations suggest 